\title{
Derivaten, risicomanagement en de balansstructuur van
} ondernemingen

\section{Piet Duffhues}

SAMENVATTING Financiële derivaten zijn onconventionele afgeleide instrumenten van de financiële markten die een belangrijke rol kunnen spelen bij het risicomanagement van ondernemingen. Dit management kan echter ook op andere wijze plaatsvinden zoals door middel van investeringen en de keuze van de vermogensstructuur. Dit artikel beschrijft de theoretische relatie tussen derivaten, risicomanagement en de balansstructuur. Geen ad hoc-benadering maar een integrale benadering is vereist. Dit leidt tot het onderscheid tussen interne en externe hedges en de keuze daartussen. Projectie vindt plaats op de (markt)waarde van de onderneming als referentiedoelstelling. De theoretische voor- en nadelen van derivaten worden uitvoerig besproken. Empirisch onderzoek bevestigt in het algemeen het nut van derivaten. Een belangrijke negatieve eigenschap is de mogelijkheid dat tijdens de looptijd van het derivaat bijstortingen moeten plaatsvinden. Met deze integrale benadering van het onderwerp wordt beoogd de verkaveling in ondernemingsfinanciering die de gangbare literatuur kenmerkt te doorbreken. Twee niveaus van risicomanagement worden onderscheiden. Deze geven inzicht in kortzichtig en fundamenteel risicomanagement. Dit onderscheid vergemakkelijkt het zicht op de oorzaken van de financiële crisis sinds 2007. Verschillende criteria voor het gebruik van derivaten in een praktische setting worden aangereikt.

RELEVANTIE VOOR DE PRAKTIJK Weinig onderwerpen uit het vak ondernemingsfinanciering zijn zo bekend en tegelijkertijd zo beladen als het gebruik van financiële derivaten. Er is veel negatieve publiciteit geweest over deze instrumenten. Daar waar deze instrumenten hun nut hebben bewezen, is publiciteit nauwelijks waarneembaar. Dit artikel bespreekt de vele argumenten pro en contra het gebruik van derivaten. Het geeft een nieuw overzicht van de verschillende criteria die bij de keuze uit de meest gangbare derivaten een rol moeten spelen.

\section{Inleiding en achtergrond}

Op 16 februari 2013 scheerde een meteoriet langs de aardbol die grote schade had kunnen aanrichten aan mensen en milieu. Deskundigen hadden berekend dat het risico op een botsing met de aardbol nagenoeg nihil was omdat de baan van de meteoriet niet wees op een naderende inslag. Het liep inderdaad goed af, maar er was wel een risico geweest. Op dezelfde dag was in Rusland eerder op de dag een ander ruimtevehikel ingeslagen dat 30 miljoen euro schade aanrichtte aan woningen en bedrijven, maar vooral ook aan ongeveer 1200 mensen die aanzienlijk lichamelijk letsel opliepen. Onbekend is of de autoriteiten het risico op dergelijke financiële schades hadden verzekerd - het lijkt weinig waarschijnlijk - maar de mogelijkheid hiertoe bestond in beginsel wel, bijvoorbeeld door een transactie in financiële derivaten of zoals deze ook worden genoemd 'afgeleide financiële instrumenten'. De waarde van deze derivaten wordt in belangrijke mate bepaald door de prijs van de 'onderliggende waarde' zoals de rente, of een valutakoers. Met derivaten gaat het altijd om een contract op een bepaald moment, met meestal een bank of beurs, dat op dat startmoment meestal geen geldstroom tot gevolg heeft tussen partijen maar mogelijk wel in de toekomst. Denk hierbij aan termijncontracten en opties. Terugkerend naar de meteoriet is het van belang dat op financiële markten sinds de jaren tachtig van de vorige eeuw zogeheten catastrofederivaten verhandeld worden tussen kopers en verkopers van rampenrisico's. Een mogelijke ramp is in dat geval de onderliggende waarde. Dit derivaat is slechts één voorbeeld van een deelmarkt voor derivaten. Op zeer vele andere terreinen dan op het terrein van het risico getroffen te worden door puin uit de ruimte, zijn sinds de jaren zeventig van de vorige eeuw 'financiële derivaten' ontwikkeld met het doel om partijen die daaraan behoefte hebben verzekering te bieden tegen een bepaald risico tegen betaling van een contraprestatie (bijvoorbeeld maar niet per se in de vorm van een premie) aan een tegenpartij die het risico overneemt. 


\section{Definitie derivaten}

Derivaten zijn complexe financiële instrumenten die worden verhandeld tussen twee partijen waarbij soms onmiddellijk een bepaalde betaling plaatsvindt van de een aan de ander (namelijk bij opties), maar waarbij in elk geval mogelijke toekomstige geldstromen tussen partijen worden gepland waarvan de realisatie afhankelijk is van onzekere toekomstige gebeurtenissen vooral op markten. Het is dus in feite handel in risico. De partij die een bepaald risico kwijt wil, dekt dat risico af. De tegenpartij neemt dat risico over maar dat kan tegengesteld zijn aan een al bestaand risico. Beide partijen dekken dan hun initieel risico af ('hedging'). Het kan echter voor een of beide partijen ook gaan om pure speculatie. Nagenoeg alle ondernemingen zeggen volgens internationaal wetenschappelijk onderzoek dat zij met deze derivaten niet speculeren. In feite doen ze dat in een aantal gevallen wel (zie paragraaf 7). Een bekend voorbeeld hiervan is wanneer een derivaat wordt aangegaan alleen op basis van 'visie' die al dan niet afkomstig is van 'deskundigen': verwachte maar onzekere toekomstige prijsontwikkelingen zoals van aandelenkoersen, valuta's en rentes zijn daarbij doorslaggevend motief om de transactie aan te gaan.

Een belangrijke schaduw over derivaten is dat dergelijke transacties niet alleen kosten met zich meebrengen maar ook nieuwe risico's kunnen introduceren. Dat laatste is in de praktijk maar al te zeer gebleken, zoals in de in Nederland in 2012 geruchtmakende Vestia-casus waarin een woningcorporatie zich vertilde aan een grote positie in renteswaps (Hoogendoorn, 2013). Deze schaduwzijden worden in dit artikel belicht.

\section{Financieringsliteratuur verkaveld}

De financieringsliteratuur over derivaten en risicomanagement van ondernemingen is sinds de jaren zeventig van de vorige eeuw in sterke mate uitgebreid maar is in belangrijke mate verkaveld (Duffhues, 2000). Dat is op zichzelf gezien een te waarderen ontwikkeling, maar de analyse is veelal te fragmentarisch zoals gericht op de vraag welke derivaten er zoal zijn, hoe heeft de markt voor derivaten zich ontwikkeld, welke onderliggende waarden kunnen worden gehedged en hoe derivaten te verantwoorden in de jaarrekening. Een geïntegreerde aanpak in een algemeen theoretisch en praktisch verantwoord raamwerk waarin de verschillende deelaspecten een plaats hebben, ontbreekt ten enenmale. Derivaten zijn niet zonder meer optimale risicobeheersingstechnieken. In dit artikel willen wij een bijdrage leveren aan het denken over het opheffen van deze verkaveling. In het bijzonder zal aandacht worden besteed aan het onderscheid tussen separate en ingebouwde derivaten, aan de keuze uit de veelheid van derivaten, aan de relatie tussen derivaten en de balansstructuur, aan de relatie tussen derivaten en de toekomstige investeringen en aan de relatie tussen deri- vaten en het liquiditeitsvraagstuk van ondernemingen. In het algemeen beperkt dit artikel zich tot niet-financiële ondernemingen.

\section{Structuur artike}

In paragraaf 2 volgt eerst een verkenning van derivaten en risicomanagement en de verfijning hiervan tot financieel risicomanagement. Ook worden alternatieve methoden van risicomanagement genoemd. Financiële derivaten worden geduid als specifieke vehikels van financieel risicomanagement. In paragraaf 3 komen de theoretische voor- en nadelen van derivaten aan de orde. Deze paragraaf is de kern van het artikel en typeert het afwegingsprobleem om deze instrumenten wel of niet in te zetten. In paragraaf 4 worden twee niveaus van financieel risicomanagement geanalyseerd. Daarbij wordt het onderscheid opgevoerd tussen partiële en integrale toepassing van derivaten en de afweging tussen beide geïntroduceerd. Een handreiking met zeven praktisch gekozen criteria voor de keuze uit het arsenaal van beschikbare derivaten wordt aangereikt in figuur 1 . In paragraaf 5 volgt een beschouwing over de relatie tussen derivaten en de beide zijden van de balans. In een aantal gevallen kunnen derivaten in een complementaire rol heel nuttig zijn. In paragraaf 6 volgt een analyse van de optimale hedgestrategie startend vanuit het streven naar optimale liquiditeit. Risicomanagement blijkt een belangrijk onderdeel van het streven naar liquiditeit van de onderneming. Deze paragraaf bevat een uitwerking van het onderscheid tussen separate en ingebouwde derivaten door verschillen tussen die twee soorten te traceren. In paragraaf 7 volgt aandacht voor het praktisch gebruik van derivaten. De resultaten van het empirisch onderzoek sluiten op hoofdlijnen aan op de theorie. Er zijn echter afwijkingen die zeker voor verbetering in aanmerking komen. In paragraaf 8 volgt een samenvatting en conclusies van het artikel als geheel.

\section{Risicomanagement}

Derivatentransacties maken 'slechts' deel uit van het veel meer omvattende risicomanagement van een organisatie. Risicomanagement definiëren we heel algemeen als het gedrag van natuurlijke en rechtspersonen dat betrekking heeft op het streven om reeds bestaande dan wel verwachte (toekomstige) risico's te beheersen. Met beheersen wordt niets anders bedoeld dan het in goede banen leiden van het desbetreffende risico.

\subsection{Financieel risicomanagement}

Er zijn veel soorten risico's denkbaar zoals technische risico's, klimaatrisico's en productierisico's. Gaat het over financieel risicomanagement dan gaat het over financiële risico's zoals in dit artikel. Beleggers in aandelen bijvoorbeeld denken in sterke mate in termen van risico's; zij veranderen het risicoprofiel van hun 
portefeuille als dat gunstig lijkt voor het behalen van rendement. In lijn met de definitie van risicomanagement kan beheersing van risico's betrekking hebben op zowel verkleining als op vergroting van risico's. Daaruit volgt dat het risicomanagement qua richting strikt genomen neutraal is. Beleggers in aandelen vergroten hun risico indien voorheen werd belegd in risicoloze effecten of zekere spaarvormen. Het risico neemt toe. In nietfinanciële ondernemingen wordt in de praktijk het risicomanagement echter veelal eng geïnterpreteerd namelijk als het streven om risico's af te wentelen (ergo: te verkleinen) op andere partijen, dus opterend vanuit de gezichtshoek van de risico-overdragende partij.

\subsection{Alternatieve vormen van risicomanagement}

Financieel risicomanagement kan met derivaten worden uitgevoerd maar er zijn daarnaast verschillende andere mogelijkheden om risico's te beheersen. Financieel risicomanagement kan primair vorm krijgen door de keuze van de activa- en de passivastructuur van de balans. Een voorbeeld is het doen van extra investeringen (Emanuels \& De Munnik, 2005). De activastructuur van elektriciteitsondernemingen wordt beïnvloed door de afweging tussen de mate van verticale integratie en het gebruik van termijncontracten (Aïd et al., 2011): beide hebben betrekking op het risico van de onderneming maar zijn onderling alternatieven; soms is verticale integratie superieur zodat hedging met derivaten achterwege kan blijven. Aan de passivazijde van de balans betekent de aanwezigheid van meer of minder eigen vermogen dat risico's die een onderneming loopt meer of minder worden overgedragen aan bepaalde externe vermogensverschaffers met alle gevolgen van dien voor het risico van faillissement van de onderneming. De keuze van de vermogensstructuur is dan ook een uiting van risicomanagement optima forma. Deze keuze beïnvloedt het totale risico van de activa dat niet gegeven is met de keuze van de activa alleen; de vermogensstructuur levert een eigen bijdrage (Duffhues, 2002a).

Gesteld kan in elk geval worden dat de opkomst van derivaten sinds de jaren zeventig van de vorige eeuw het aantal keuzemogelijkheden voor het plegen van risicomanagement aanzienlijk heeft verruimd (Duffhues, 1993). Dit is zonder meer een winstpunt ook wanneer daarbij onmiddellijk wordt aangetekend dat derivaten ook belangrijke nadelen met zich mee kunnen brengen. Derivaten bezitten kenmerken die een verbetering van het risicomanagement kunnen inhouden ten opzichte van de oude situatie. In paragraaf 3 wordt dit toegelicht.

\section{Theoretische beoordeling}

In de academische maar ook in de meer praktijkgerichte literatuur wordt het gebruik van derivaten om ver- schillende redenen in het algemeen per saldo gerationaliseerd (zie paragraaf 7). Theoretische en praktische aspecten spelen daarin een hoofdrol. Hierna volgt een dwarsdoorsnede van de overwegend door binnen- en buitenlandse auteurs gehanteerde motieven. Wij maken daarbij een onderscheid tussen pro- en contra- argumenten.

\subsection{Argumenten pro}

$\mathrm{Na}$ kennisneming van de leidende artikelen in de financieringsliteratuur van de voorbije vijfentwintig jaar kan worden gesteld dat het gebruik van derivaten door ondernemingen tenminste met de volgende zes argumenten wordt verdedigd.

1. Lagere faillissementskosten en lagere 'cost of capital'. Derivaten kunnen worden gearrangeerd met het doel om de liquiditeitsdruk van rentebetalingen te verminderen. Dit wordt bereikt door de periodieke rentebetalingen qua hoogte te laten mee-ademen met de fluctuaties in de waarde van de onderneming. De onderneming betaalt volgens een dergelijke regeling, dankzij bijvoorbeeld een rentederivaat, in moeilijke tijden een lagere rente dan in voorspoedige tijden. Daardoor komt ze minder snel in liquiditeitsmoeilijkheden. De hedge draagt dus bij aan het flexibiliseren van de kasstromen (Mello \& Parsons, 1999, 2000). Het insolventierisico neemt af. Lagere faillissementskosten leiden tot een hoger residu van kasstromen. Daardoor zal de ondernemingswaarde stijgen waarvan de vermogensverschaffers profiteren. Normaliter zullen hiervan de aandeelhouders meer profiteren dan de obligatiehouders. De 'cost of capital' zal ook dalen omdat derivaten een efficiënter instrument zijn om de economische lading van een bestaand financieringscontract te veranderen dan een vastrentende lening eerst af te lossen en daarna een nieuwe variabelrentende lening aan te trekken. Een derivaat kan hetzelfde doel bereiken met minder transactiekosten. Deze zijn een component van de 'cost of capital'.

2. Belastingvoordelen. Derivatengebruik kan door een betere rating de kredietwaardigheid verhogen zodat meer vreemd vermogen kan worden aangetrokken. Denk hierbij aan de introductie van een - het garantievermogen versterkende ${ }^{1}$ - achtergestelde lening (die twee ingebouwde putopties bevat) waarvan de opbrengst wordt gebruikt om aandelen in te kopen. Het vreemd vermogen is daarna toegenomen. Het eigen vermogen wordt verlaagd met het bedrag van de achtergestelde lening. Het balanstotaal blijft gelijk. De vermogensstructuur bevat hierna meer vreemd vermogen. Op het extra vreemd vermogen kan de onderneming additionele belastingvoordelen behalen door meer aftrek van rentebedragen. Die aftrek ontbeerde ze voorheen toen het eigen vermogen nog niet 
was gereduceerd.

3. Onderinvestering voorkómen. Ondernemingen die een kastekort ervaren als hun brutokasstroom (voor aftrek van investeringen) in een toekomstige periode teleurstelt, waardoor hun investeringen wegens gebrek aan financieringsmogelijkheden eventueel worden afgeremd, derven waarde. Deze waarde neemt de vorm aan van de netto contante waarde van reeds goedgekeurde investeringen. Deze derving van waarde als gevolg van onderinvestering kan worden voorkómen door de liquiditeitshandhaving van de onderneming met behulp van de inzet van derivaten veilig te stellen. De derivaten betalen dan uit op hetzelfde moment dat de investering moet plaatsvinden. De investeringen kunnen dan normaal doorgang vinden (Froot, Scharfstein \& Stein, 1994; Mello \& Parsons, 1999, 2000).

4. Operationele voordelen. Wanneer een onderneming haar liquiditeit beter bewaakt, wordt zij minder vaak overvallen door verhoging van operationele kosten in bestaande activiteiten die ontstaan als gevolg van een te krappe liquiditeit zoals boetes wegens te late betaling, reputatieverlies en het moeten derven van korting voor contante betaling van facturen.

5. Grotere onafhankelijkheid van financiële markten. Ondernemingen die erin slagen zich financieel zelfstandig te maken door gebruik van derivaten, hoeven minder vaak een beroep te doen op de financiële markten voor het binnenhalen van vermogen omdat ze dit zelf genereren juist dankzij derivatengebruik. De gang naar de financiële markten is voor veel ondernemingen een kwelling die, indien mogelijk, wordt vermeden. Nederlandse banken hebben bijvoorbeeld weinig gebruikgemaakt van de mogelijkheid om nieuwe aandelen uit te geven. ${ }^{2}$ Door geavanceerd treasury-management neemt hun financiële autarkie derhalve toe. Dat heeft ook een negatieve zijde (zie contra-argument 7 hierna).

6. Grotere flexibiliteit met derivaten als marktomstandigheden zich wijzigen. Het kopen en verkopen van derivaten kan plaatsvinden op goed georganiseerde markten zodat snel en goedkoop kan worden aangepast.

Voor een kwantitatieve analyse van de invloed van risicomanagement op de hoogte van de 'cost of capital' (hierboven met name 1 en 2 ) wordt verwezen naar Doherty (2005).

\subsection{Argumenten contra}

Tegenover deze argumenten pro staan echter ook verschillende nadelen van het gebruik van derivaten. We noemen de volgende acht argumenten contra:

1. Het ontstaan van nieuwe risico's (kredietrisico, liquiditeitsrisico, operationele risico's). Krediet- of tegenpartijrisico ontstaat bij het aangaan van een deriva- tentransactie omdat men over en weer aan nieuwe toekomstige verplichtingen moet voldoen. Mogelijk kan de tegenpartij van het derivaat niet presteren waardoor verlies ontstaat. Het liquiditeitsrisico ontstaat doordat tijdens de looptijd van het derivaat mogelijk bijstortingen wegens het stellen van onderpand moeten plaatsvinden op eis van de tegenpartij. Dit wanneer de prijsontwikkeling van de onderliggende waarde daartoe aanleiding geeft. Dit kan grote sommen geld vergen van de onderneming (zie de Vestia-casus in 2012). Operationele risico's betreffen eventuele fouten in de contracten en mogelijke fraude van medewerkers van de treasury-afdeling.

2. Extra opleidingskosten voor hooggekwalificeerd treasury-personeel.

3. Extra monitoringkosten wegens de complexiteit van derivaten en de grote veranderlijkheid van de prijs van derivaten zowel in de partiële als de integrale benadering.

4. Meer dispuut met de accountant over de boekingswijze van derivaten in de balans en resultatenrekening (De Vries \& Veuger, 2013).

5. Meer dispuut met de fiscale autoriteiten omdat sommige derivaten de etikettering van hybride vermogenstitels beïnvloeden: is rente wel of niet aftrekbaar van de winst?

6. Meer dispuut met de rating instituten omdat elk derivaat een eigen beoordeling moet ondergaan bij de rating agency.

7. De dreiging van een verminderde kwaliteit van de corporate governance (en derhalve een vergroot agencyprobleem) als het een beursonderneming betreft omdat de graad van afhankelijkheid van het management ten opzichte van de financiële markten afneemt: derivaten kunnen immers zorgen voor goed getimede aanvullende zelffinanciering wanneer de basisgeldstroom van de onderneming stokt. Dit agencyprobleem en bijbehorend waardeverlies voor de aandeelhouders kan zichtbaar worden in een benedenmaatse kwaliteit van de jaarverslaggeving en meer algemeen in een zwakke externe communicatie. Gaat het om besloten ondernemingen dan speelt dit gevaar veel minder: de lijnen zijn er meestal aanzienlijk korter.

8. Meer reputatierisico doordat de onderneming negatief in de publiciteit kan komen wanneer derivaten niet het beoogde doel bereiken of ronduit een vergissing zijn geweest. Er kan ook fraude worden gepleegd. Bij het grote publiek staan derivaten in het algemeen niet hoog aangeschreven.

Gelet op deze contra-argumenten verdient de komst van derivaten voor velen dan ook geen applaus. Dat geldt zeker voor het grote publiek dat hoofdzakelijk geleid wordt door de media die negatieve ervaringen met derivaten uitvoerig plegen te melden maar de positieve 
ervaringen achterwege laten, en mogelijk zelfs niet kennen. Heel bekend is de kwalificatie van de Amerikaanse belegger Warren Buffett die in 2003 al uitsprak dat derivaten masssavernietigingswapens kunnen zijn die een dodelijk gevolg kunnen hebben voor partijen. ${ }^{3}$ Hij doelde hiermee op het mogelijke liquiditeitseffect van de waardeontwikkeling van derivaten tijdens de looptijd van het derivaat die tot nieuwe onvoorspelbare hoge geldstromen kan leiden. Dit is een liquiditeitseffect van het gebruik van derivaten. Het gebruik van derivaten en de bewaking van de liquiditeit van een organisatie vertonen dan ook een duidelijke samenhang. Liquiditeitsbeleid en risicomanagement zijn onderling in sterke mate verweven. Behalve kritische opmerkingen van bekende beleggers als Warren Buffett is ook veel kritiek te beluisteren na de instorting van het financiële systeem in het Westen sinds 2007/2008. Deze crisis wordt vaak toegeschreven aan de invloed van het gebruik van derivaten en hiermee samenhangend aan mislukt risicomanagement. In het bijzonder wordt daarbij gewezen op het onoordeelkundig gebruik van kredietderivaten waarmee kredietrisico's kunnen worden gemanaged. Deze zijn eerst ontstaan in 1997 maar hebben een hoge vlucht genomen in het eerste decennium van deze eeuw. Dit alles stemt als vertrekpunt niet optimistisch ten aanzien van de algemene beoordeling van de merites van derivaten aan het eind van dit artikel. Toch kan worden geconstateerd dat het gebruik van derivaten onverminderd is gegroeid (vergelijk Bulkmans, 2013). Blijkbaar zijn de verschillende her en der opgetreden negatieve ervaringen niet doorslaggevend. Zo handelde Warren Buffett zelf in derivaten, ook na het uitspreken van zijn eerder vermelde dodelijke kritiek. Het gebruik van derivaten kan verschillende positieve aspecten bezitten. Daarbij denken we primair aan de relatie tussen het gebruik van derivaten en het liquiditeitsbeheer van organisaties, secundair aan het besparen op transactiekosten en aan het optuigen van de jaarrekening (De Vries \& Veuger, 2013).

\subsection{Implicaties en conclusies}

In alle zes gevallen van de pro-argumenten neemt de contante waarde van de verwachte operationele kasstromen na belasting toe. Hierdoor neemt de brutowaarde van de onderneming voor de vermogensverschaffers toe. De nadelen zijn voor de algemene situatie moeilijk te kwantificeren. Op basis van de genoemde zes motieven pro derivatengebruik kan worden vastgesteld dat het risicomanagement van ondernemingen in zeer overwegende mate neerkomt op het optimaliseren van de liquiditeit van de onderneming opdat ook financieel moeilijke toekomstige kasarme scenario's gemakkelijker kunnen worden overleefd. Derivaten kunnen in dergelijke scenario's zorgen voor de aanvulling van de kas doordat derivaten alsdan uitbetalen zodanig dat geplande investeringen ongestoord doorgang kunnen vinden. De noodzakelijke investeringsuitgaven worden in die situatie deels gefinancierd uit de opbrengst (payout) van de aangelegde derivaten. Wanneer anderzijds gunstige kasrijke scenario's aan de orde zijn, kunnen investeringen uit de cash flow worden gefinancierd zodat de aangelegde derivaten geen opbrengst hoeven op te leveren.

Ten minste vier conclusies tekenen zich af:

\section{Risicomanagement en liquiditeitsbewaking}

Het risicomanagement van ondernemingen is in essentie niet veel anders dan het moderne jargon voor een zeer traditionele doelstelling van de financiële leiding waarover nauwelijks meer wordt geschreven alsof het probleem niet meer zou bestaan: het te allen tijde bewaren van de liquiditeit van de onderneming zodanig dat de toekomstige geplande ontwikkeling van de onderneming niet wordt geschaad. Liquiditeitshandhaving is niet alleen een kwestie van overleving om voldoende transactiekas te bezitten maar heeft ook als doel de 'cost of capital' te reduceren en de kredietwaardigheid te verbeteren. Het aanhouden van optimale liquiditeit met behulp van derivaten kan een goed substituut zijn voor het aanleggen van een hogere solvabiliteitsratio. Gewezen wordt op de ruime tot zeer ruime kasposities van veel ondernemingen sinds het ontstaan van de financiële crisis en het aanhouden van ruime open kredietlijnen bij banken. De klassieke voorzorgs- en speculatiemotieven voor het aanhouden van liquiditeiten zijn hierin herkenbaar (Duffhues, 2002a).

\section{Beurs- en niet-beursondernemingen}

Een tweede conclusie is dat ondernemingen die geen belemmeringen kennen in hun toegang tot de externe kapitaalmarkten van eigen en vreemd vermogen minder behoefte hebben aan een scherp financieel risicomanagement en daarbinnen aan het gebruik van derivaten. Dit lijkt erop te wijzen dat beursondernemingen in het algemeen bevoorrecht zijn boven niet-beursondernemingen. In het midden- en kleinbedrijf is de behoefte aan risicomanagement op basis hiervan groter. Toch is dit zeer betrekkelijk. Ook grote gevestigde beursondernemingen geraken soms in grote financiële problemen ${ }^{4}$ die zij niet door zelffinanciering kunnen oplossen terwijl veel rendabele MKB-ondernemingen ${ }^{5}$ weinig remmingen ondervinden om hun investeringen te realiseren. Van groot belang hierbij is uiteraard ook de vraag of een onderneming grote expansieplannen heeft. Oordeelkundig gebruik van derivaten als deel van het risicomanagement kan het investeringstempo van beurs- en niet-beursondernemingen doen opvoeren. Een efficiënt werkende derivatenmarkt ondersteunt de liquiditeit van het bedrijfsleven en is als zodanig van grote betekenis voor de nationale groei van de economie. 


\section{Risicomanagement is complex}

Risicomanagement met gebruikmaking van derivaten roept complexe vraagstukken op in de organisatie en in het verkeer met diverse externe partijen. Een van de grootste problemen is dat managers van afzonderlijke risico's (zoals debiteurenrisico, renterisico enz.) geen weet hebben van de invloed van hun risicomanagementbeleid op het totale risico van de onderneming (zie paragraaf 6). Deel(afdelings)oplossingen kunnen daarbij contrair uitwerken. In verband hiermee moeten hoge eisen worden gesteld aan de kwaliteit van het risicomanagement. In het algemeen is dit in grote ondernemingen gemakkelijker op te lossen dan in midden- en kleinbedrijven waar vaak een kennisachterstand bestaat (Fraser \& Simkins, 2007; Stulz, 1996, 2003, 2004, 2008).

\section{Risicomanagement is potentieel en zelfs substantieel waar- decreërend}

Diverse voorbeelden uit de praktijk tonen aan dat zwak risicomanagement zoals het niet opheffen van mismatches in kasstromen en/of in reële waardes tot grote verliezen kan leiden en tot het ontstaan van wantrouwen op de financiële markten. Investeringen moeten worden uitgesteld of geannuleerd. Rating instituten kondigen verlaging van rapportcijfers aan voor bestaande en/of nieuwe leningen. Aandeelhouders verhogen hun risicopremie. De 'cost of capital' neemt toe.

\section{Twee niveaus van risicomanagement}

Hierboven werd de complexiteit van waardecreërend risicomanagement al genoemd.

Deze vloeit in belangrijke mate voort uit de misvatting dat locale managers van deelrisico's kunnen overzien wat goed of slecht is voor het totale risico van een onderneming. In verband hiermee kunnen twee typen van risicomanagement worden onderscheiden. Deze worden toegelicht in paragraaf 4.1 en 4.2.

\subsection{De instrumentele (of partiële of micro- of silo)benadering}

De financieringsliteratuur heeft sinds de jaren zeventig van de vorige eeuw vooral aandacht besteed aan een analyse van de verschillende soorten derivaten en hun toepassingsmogelijkheden. Ik noem dat de instrumentele of silobenadering' van derivaten (Duffhues, 2002b).

In jaarverslagen is deze benadering de standaard geworden. Ondernemingen rapporteren in hun jaarverslagen over verschillende risico's en wel separaat per risicosoort (Duffhues, 1993). Daarbij wordt vervolgens in al dan niet heldere bewoordingen vermeld welke strategie bij die bepaalde risicosoort wordt gevolgd. Stilzwijgend wordt daarbij verondersteld dat het 'probleem' min of meer vaststaat dus gegeven is. Met 'probleem' wordt bedoeld dat er bijvoorbeeld een renterisicoblootstelling ontdekt is (ook wel rente-exposure genoemd). Hetzelf- de geldt voor valuta-exposures en voor grondstoffenexposures. Dit is het terrein van wat ik noem het 'operationele risicomanagement'. Financiële instrumenten en technieken spelen daarin de boventoon. Jaarverslaggevings-, fiscale en corporate governance-aspecten moeten een zekere weging krijgen in de besluitvorming over de keuze van een financieel derivaat. Meestal gaat het om een behoefte om een risico af te dekken, dus over wat wordt genoemd een 'financial hedge'. Kenmerkend hiervoor is dat een bestaande of verwachte overschotof tekortpositie in een bepaald(e) activum of geldstroom wordt geneutraliseerd door een tekort- respectievelijk overschotpositie ernaast te plaatsen. In een 'perfecte' hedge zijn de voor- en nadelen van toekomstige prijsontwikkelingen aan elkaar gelijk zodat de hedge inderdaad het risico neutraliseert: de combinatie is risicoloos gemaakt. Perfecte hedges zijn in de praktijk echter moeilijk realiseerbaar bijvoorbeeld doordat er 'basisrisico' bestaat tussen de prijsontwikkeling van de positie en van het hedge-instrument. Looptijdverschillen en transactiekosten spelen potentieel eveneens een verstorende rol evenals verslaggevingsaspecten. Zo kon geruime tijd in de jaarrekening waardering van derivaten plaatsvinden niet tegen de reële waarde maar tegen kostprijs en werden deze instrumenten 'off balance' verwerkt (De Vries \& Veuger, 2013).

\subsection{De strategische (of integrale of holistische of macro) bena- dering: Enterprise Risk Management (ERM)}

Naast de instrumentele benadering is het 'strategische' gebruik van derivaten veel minder duidelijk belicht, hoewel uiterst belangrijk. Hierbij is de startpositie in een bepaald risico niet langer een gegeven maar een te optimaliseren grootheid als deel van een groter geheel van risico's. De interactie tussen de werking van het hedge-instrument en de onderliggende waarde staat hierin centraal. Het resultaat van de analyse kan zijn dat tegelijk met het kiezen van een hedge ook de keuze van de concurrentiestrategie wordt geoptimaliseerd. Deze benadering grijpt dus in over de gehele balans (zie de titel van dit artikel) en blijft dus niet beperkt tot het wel of niet afdekken van het renterisico van een gegeven individuele balanspost (debet of credit) of een individuele geldstroom (plus of minus) zoals in de instrumentele benadering gebeurt. Deze benadering verdient de voorkeur als men streeft naar een eenduidig doel van de onderneming waarop de ogen van alle risicomanagers worden gericht in casu waardeschepping voor de onderneming.

\section{Eenduidige doelstelling gewenst}

Een belangrijke vraag is op welke wijze het gebruik van derivaten in het algemeen kan worden getoetst. Dat vereist het formuleren van een doelstelling. In de economische literatuur is de doelstelling het streven naar waardeschepping. In strikt theoretische zin vindt vol- 
gens de klassieke financieringsliteratuur van Modigliani en Miller (1958) geen waardeschepping plaats zolang men uitgaat van het bestaan van perfecte financiële markten. Ondernemingen kunnen in dergelijke markten zonder beperkingen met een druk op de knop elk kastekort of kasoverschot aanvullen respectievelijk afvoeren. Er zijn geen belemmeringen aan dit proces, ook geen verstorende belastingen. Transactiekosten bestaan evenmin en informatie is voor eenieder op gelijke schaal en tijd beschikbaar. Dit ideaalbeeld van de werking van financiële markten is weliswaar geen realiteit maar wordt wel benaderd door die ondernemingen die voldoen aan de hoogste eisen van rendement, liquiditeit en kredietwaardigheid. Onverwachte prijsontwikkelingen in rente, valuta's en grondstoffenprijzen worden in dit model flexibel opgevangen door de interactie tussen de ondernemingen en de geld- en kapitaalmarkten. Dit accommoderend gedrag vergemakkelijkt het financiële beleid van dergelijke ondernemingen zonder het waardestreven te veronachtzamen. ${ }^{6}$ Het impliceert dat het derivatengebruik door dergelijke ondernemingen in beginsel dan ook beperkt zal zijn en dat, voor zover men deze derivaten toch gebruikt, dit niet wordt gedomineerd door voordelen uit hoofde van prijsverschillen (die zijn er strikt genomen in die wereld niet of nauwelijks) maar uit hoofde van fiscale aspecten en verslaggevingsaspecten. ${ }^{7}$ In werkelijkheid zijn bijna alle ondernemingen echter beperkt in de geldstromen richting van en naar de financiële markten zodat aan de genoemde kenmerken van het ideaalbeeld niet wordt voldaan. Daaraan kan nog worden toegevoegd dat ook veel beursondernemingen een emissie van aandelen vaak uitstellen als laatste oplossing voor een liquiditeitstekort. ${ }^{8}$ De vraag naar de toegevoegde waarde van het gebruik van derivaten blijft derhalve relevant eigenlijk voor nagenoeg alle ondernemingen.

\subsection{Keuze uit beide benaderingen}

Wanneer men als doelstelling van de onderneming definieert het maximaliseren van de waarde van de onderneming ${ }^{9}$ als geheel is snel duidelijk dat de strategische benadering de voorkeur verdient boven de partiële benadering. Deze voorkeur is gegrondvest in de algemeen economische theorie en is gemeengoed in de academische financieringsliteratuur (Duffhues, 1992a; Woods, 2009). Dat houdt in dat de partiële benadering die, afgaande op wat jaarverslagen op z'n minst suggereren, in de praktijk veelal wordt gevolgd en die veel meer op de korte termijn is gericht, het risico impliceert dat de cumulatie van (micro-)hedges op separate posities niet optimaal is voor de waarde van de onderneming als geheel en op langere termijn. Dat deze kortzichtigheid in de werkelijkheid speelt, blijkt uit de dramatische gevolgen van de besluiten van banken en andere financiële instellingen om in de eerste jaren van deze eeuw grote bedragen te investeren in Amerikaanse subprime mortgages die vanaf 2007 later het ontstaan van een wereldwijde financiële crisis hebben ingeluid, terwijl de passages in de jaarverslagen glommen van tevredenheid over het gepraktiseerde risicomanagement. Het voortbestaan van verschillende ook Nederlandse banken kwam hierdoor zelfs ter discussie: te grote nadruk op de partiële kortetermijnbenadering van het risicomanagement (Duffhues, 2009). De partiële benadering tendeert naar handhaving van bestaande en op korte termijn verwachte ontwikkelingen in de balans en de resultaten (met de nadruk op de zogeheten translatie-exposure en transactie-exposures ${ }^{10}$ ) terwijl de primaire aandacht zou moeten uitgaan naar het beheersen van de economische exposure van de onderneming als geheel (macro-hedging). Over die economische exposure zelf waarbij de kwaliteit van de concurrentiepositie centraal staat, wordt door ondernemingen nauwelijks gerapporteerd. Over de beheersing daarvan nog minder.

Figuur 1 Enkele criteria (nrs. $2 \mathrm{t} / \mathrm{m}$ 8) voor de keuze uit vier separate derivaten (kolom 1); kolommen 3 en 4 zijn tentatief ingevuld

\begin{tabular}{|c|c|c|c|c|c|c|c|}
\hline $\begin{array}{l}\text { Financieel } \\
\text { instrument } \\
\text { (1) }\end{array}$ & $\begin{array}{l}\text { Voorwaardelijk/ } \\
\text { Onvoorwaardelijk } \\
\text { (2) }\end{array}$ & $\begin{array}{l}\text { Looptijd } \\
\text { (3) }\end{array}$ & $\begin{array}{l}\text { Liquiditeit markt } \\
\text { (4) }\end{array}$ & $\begin{array}{l}\text { Maatwerk/ } \\
\text { confectie } \\
\text { (5) }\end{array}$ & $\begin{array}{l}\text { Krediet- of te- } \\
\text { genpartijrisico } \\
\text { (6) }\end{array}$ & $\begin{array}{l}\text { Liquiditeitsrisico } \\
\text { van instrument zelf } \\
\text { (7) }\end{array}$ & $\begin{array}{l}\text { Verslaggevings- } \\
\text { aspecten } \\
\text { (8) }\end{array}$ \\
\hline Forwards & Onvoorwaardelijk & $<2$ jaar & Ruim & Maatwerk & $\mathrm{Ja}$ & $\begin{array}{c}\text { Ja } \\
\text { (Onderpand) }\end{array}$ & $\begin{array}{l}\text { Hedge-accounting } \\
\text { toegestaan? }\end{array}$ \\
\hline Futures & Onvoorwaardelijk & $<1$ jaar & $\begin{array}{c}\text { Zwak in Amsterdam } \\
\text { Ruim in de VS }\end{array}$ & Confectie & Nee & $\begin{array}{c}\mathrm{Ja} \\
\text { (Marking to market) }\end{array}$ & $\begin{array}{l}\text { Hedge-accounting } \\
\text { toegestaan? }\end{array}$ \\
\hline Swaps & Onvoorwaardelijk & $<50$ jaar & Ruim & Maatwerk & $\mathrm{Ja}$ & $\begin{array}{c}\text { Ja } \\
\text { (Onderpand) }\end{array}$ & $\begin{array}{l}\text { Hedge-accounting } \\
\text { toegestaan? }\end{array}$ \\
\hline Opties: Beurs & Voorwaardelijk & $<2$ jaar & Matig & Confectie & $\begin{array}{l}\text { Nee voor koper } \\
\text { Nee voor verkoper }\end{array}$ & $\begin{array}{l}\text { Nee voor koper } \\
\text { Ja voor verkoper }\end{array}$ & $\begin{array}{l}\text { Hedge-accounting } \\
\text { toegestaan? }\end{array}$ \\
\hline Onderhands & Voorwaardelijk & $<10$ jaar & Beperkt & Maatwerk & $\begin{array}{l}\text { Ja voor koper } \\
\text { Nee voor verkoper }\end{array}$ & $\begin{array}{l}\text { Nee voor koper } \\
\text { Ja onderpand }\end{array}$ & $\begin{array}{l}\text { Hedge-accounting } \\
\text { toegestaan? }\end{array}$ \\
\hline
\end{tabular}




\subsection{Keuzecriteria met betrekking tot het gebruik van derivaten}

Eerder is besproken dat een veelvoud van financiële derivaten beschikbaar is voor het hedgen van een bepaalde positie (zie ook Bulkmans, 2013). Die instrumenten concurreren met elkaar. Ook in de integrale benadering kunnen derivaten wel degelijk een rol spelen, zij het als complementair in te zetten instrumenten op de keuzes over investeren en financieren. Denk in het kader van de strategiekeuze aan het kopen van opties op de aandelen van een beoogde overnamekandidaat. Derivaten hebben vaak het karakter van termijncontracten (forwards, futures en swaps). Verschillende criteria spelen een rol in de keuze van het derivaat. Het overzicht van figuur 1 is een hulpmiddel om de keuze van een derivaat voor te bereiden.

Alle vier soorten derivaten kunnen bijdragen aan het scheppen van waarde door een onderneming. Forwards, futures en swaps zijn onvoorwaardelijke derivaten: beide partijen gaan harde verplichtingen aan om te presteren. Opties zijn daarentegen voorwaardelijk; opties zijn rechten en geen plichten om te kopen. Mogelijk wordt de optie niet uitgeoefend door de koper van de optie. Uit figuur 1 blijkt dat forwards en futures in het algemeen een korte looptijd kennen. Het grote verschil tussen deze twee derivaten schuilt in het karakter van maatwerk bij forwards en het karakter van standaard of confectie bij futures. De liquiditeit van deze twee contracten is in het algemeen goed. Swaps hebben meestal een lange looptijd en zijn ook als maatwerk te betitelen. Vooral rente- en valutaswaps kennen een liquide markt. Swaps zijn in feite bundels van forwards. Opties zijn voor de kopers een recht, voor de verkopers een plicht. De verhandeling op optiebeurzen is beperkt, dit geldt ook voor onderhandse markten waar maatwerk qua bedragen en looptijden overheerst (Over The Counter $=$ OTC). Kolom 6 geeft aan dat het krediet- of tegenpartijrisico optreedt bij forwards en swaps en daarnaast bij onderhandse opties in de positie van de koper. De organisatie van futuresmarkten en beursopties garandeert de afloop van futures- en optiecontracten (bijvoorbeeld Stulz, 2003). De koper van een onderhandse optie loopt wel tegenpartijrisico omdat de schrijver in gebreke kan blijven. De verkoper van een optie loopt geen tegenpartijrisico omdat alleen de koper bepaalt wat er gebeurt: uitoefenen en betalen of niet uitoefenen.

Kolom 7 geeft aan dat bij alle financiële instrumenten de kans bestaat dat tijdens de looptijd liquiditeiten afvloeien als de prijsontwikkeling van de onderliggende waarde daartoe aanleiding geeft. De enige uitzondering daarop is de koper van een optie die tijdens de looptijd van de optie nooit hoeft bij te betalen omdat hij beschikt over een recht en geen plicht heeft om de optie uit te oefenen. Hij moet uiteraard wel de uitoefenprijs betalen als hij besluit de optie uit te oefenen.
Kolom 8 ten slotte handelt over de vraag of de wijze van verslaggeving in de jaarrekening van een onderneming invloed kan hebben op de keuze van het derivaat. Deze relatie is in een imperfecte vermogensmarkt relevant. Hierbij wordt verwezen naar de inmiddels uitgebreide set van regels omtrent hedge-accounting (De Vries \& Veuger, 2013).

\section{Derivatengebruik en balansstructuur}

Drie gevallen zijn denkbaar in de relatie tussen derivaten en balansstructuur. Dit is afhankelijk van de keuzes die ondernemingen maken. Wij lichten deze drie mogelijkheden toe en trekken conclusies in paragraaf 5.4.

\subsection{De activa- en financieringskeuze}

Tot nu toe is in dit artikel de aandacht sterk geconcentreerd op het gebruik van derivaten door ondernemingen zonder dat erop gewezen is dat in een balans zonder meer reeds een dosis risicomanagement voorkomt ook wanneer geen gebruik wordt gemaakt van derivaten. Dit geldt voor beide zijden van een balans. Aan de activazijde kunnen risico's worden gemitigeerd door te profiteren van diversificatievoordelen tussen de operationele geldstromen van conjunctureel tegendraadse activiteiten. Ook kunnen valutacocktails worden samengesteld waardoor valutavoor- en nadelen elkaar deels of geheel compenseren (Srinivasulu, 1981; Soenen, 1991). Hier komen geen derivaten aan te pas. Ook kunnen traditionele verzekeringen worden afgesloten zoals tegen brandgevaar met betrekking tot gebouwen, machines en voorraden, en verzekeringen ten aanzien van debiteurenrisico's en verouderingsrisico's met betrekking tot vaste activa. Aan de passivazijde van de balans kan - en wordt sinds decennia - de verhouding tussen eigen en vreemd vermogen gestuurd en geïnterpreteerd als een hedge-beslissing. Naarmate meer eigen vermogen wordt aangehouden, is het risico voor de onderneming als organisatie kleiner. De solvabiliteit in de balans - gedefinieerd als de verhouding van het eigen vermogen tot het totale vermogen - is derhalve een quasi-hedge die het gebruik van derivaten deels of geheel overbodig maakt. Meer winstinhouding maakt derivatengebruik ten minste voor een deel overbodig. Meer vreemd vermogen maakt dit gebruik echter meer noodzakelijk.

Dit laatste kan worden verklaard doordat een hogere financiële hefboomwerking die het gevolg is van het aantrekken van vreemd vermogen, het risico voor de aandeelhouders verhoogt.

\subsection{Separaat verworven derivaten}

Wanneer'stand alone' of separate derivaten worden verworven kunnen deze zijn geprojecteerd op bestaande of toekomstige activa en passiva die zelf geen derivaten bevatten. Een voorbeeld is een afzonderlijk gecontracteerd valutatermijncontract op een debiteurenvordering die 
luidt in Amerikaanse dollars. Een ander voorbeeld is een renteplafond kopen op een reeds bestaande lening.

\subsection{Ingebouwde derivaten: hybride financieringsvormen}

Vaak zijn derivaten ingebouwd in vormen van vooral vreemd vermogen. Men spreekt dan van 'hybride' vermogenstitels ${ }^{11}$ die een overgangsvorm zijn tussen eigen vermogen en 'rechttoe rechtaan' vreemd vermogen (Duffhues, 2006b). Doordat hybride schuldtitels bepaalde kenmerken van eigen vermogen bezitten, dragen zij bij aan het garantievermogen van een onderneming. Het derivaat neemt hierbij vaak de vorm aan van een optie. Een bekend voorbeeld is een converteerbare obligatielening die kan worden ontleed als een gewone lening aangevuld met een calloptie op de aandelen van de uitgevende onderneming. Onlosmakelijk is die calloptie verbonden met de lening. Separaat kan die calloptie niet worden verhandeld. Een andere vorm van het gebruik van ingebouwde derivaten is de vaak voorkomende achtergestelde lening; deze bestaat uit een combinatie van een gewone lening aangevuld met twee putopties (Duffhues, 2006b). ${ }^{12}$ Een derde voorbeeld is een dual-currencylening waarbij ten minste twee valuta's gelden voor de aantrekking, de rentebetaling en de aflossing. De belegger loopt hierbij een ingebouwd valutarisico omdat rente en/of aflossingsbedragen niet in de gestorte valuta plaatsvinden. Zijn positie komt overeen met het verstrekken van een gewone lening aangevuld met het schrijven van een putoptie op de aflossingsvaluta. Een modern en sterker voorbeeld van hybride vermogen is de 'contingent convertible' ofwel 'CoCo' die in het bankwezen wordt toegepast. In figuur 2 is de CoCo herkenbaar als een externe hedge in de vorm van een kapitaalmarkttransactie. Ook hierbij schrijven beleggers een putoptie in dit geval op de boekhoudkundige waarde van het eigen vermogen van de onderneming. Daardoor kan wanneer een bepaalde drempelwaarde van het eigen vermogen door verliezen neerwaarts wordt overschreden, de aflossingsplicht op de CoCo plotseling geheel of gedeeltelijk vervallen. Beleggers ontvangen voor het lopen van dit risico een extra hoge rente.

\subsection{Conclusies}

Uit de paragrafen 5.1 tot en met 5.3 kan worden geconcludeerd dat:

a. derivaten zowel separaat als ingebouwd (in andere balanstransacties) ('embedded') kunnen voorkomen.

b. de keuze van de activa- en de vermogensstructuur zonder daarbij ingebouwde derivaten te betrekken, evenzeer een vorm van financieel risicomanagement inhoudt als met gebruikmaking van separate derivaten (zie paragraaf 5.1). Deze laatste zijn niet per se nodig noch in ingebouwde noch in separaat verworven vorm. c. wanneer ingebouwde derivaten wel deel uitmaken van de balansstructuur (zie paragraaf 5.3) is het zaak de aanwezigheid van deze impliciete derivaten tegelijk met eventuele separate derivaten te betrekken in de hiervoor genoemde integrale benadering van het gebruik van derivaten met het doel de waarde van de onderneming als geheel te maximaliseren: alle derivaten hebben een plaats in de analyse.

d. er bestaat een wederzijdse afhankelijkheid of interactie tussen de keuze van de balansstructuur en het gebruik van derivaten. Optimaal derivatengebruik kan niet worden gerealiseerd zonder tegelijkertijd de balansstructuur te optimaliseren en omgekeerd. Verkaveling van deze beslissingen is in beginsel altijd suboptimaal (Duffhues, 2000).

\section{De optimale hedgestrategie}

Twee vragen rondom risicomanagement dringen zich nu op in relatie tot derivaten. De eerste vraag is wat de meerwaarde is van derivaten in het algemeen. De tweede vraag is of er een meerwaarde is van separate derivaten boven ingebouwde derivaten en zo ja welke dat is. In beide gevallen gaat het om dezelfde derivaten waartussen kan worden gearbitreerd. Het technische verschil is de mate van verbondenheid. Een separaat derivaat staat op zichzelf, is dus 'stand alone'. Een ingebouwde derivaat is onlosmakelijk verbonden met een balanspost (meestal een financieringspost). De afweging in dit vlak komt neer op het zoeken naar de optimale hedgestrategie.

\subsection{Tweeledige relatie met het liquiditeitsvraagstuk}

Derivatengebruik kan op twee manieren invloed hebben op de kans op een kastekort. Deze werken elkaar tegen hetgeen onder omstandigheden een prikkel oplevert om bij voorkeur geen derivaten te gebruiken maar een andere weg te kiezen bijvoorbeeld die van een interne hedge of een andere externe hedge door een financieringsoplossing te kiezen (zie verder in figuur 2). Hierna wordt dit toegelicht door onderscheid te maken tussen het algemene en het financieeltechnische liquiditeitsrisico.

\section{Reductie van het algemene liquiditeitsrisico}

Op deze plaats wordt de hedgebeslissing eerst toegelicht aan de hand van het derde onderdeel uit de reeks 'argumenten pro' van paragraaf 3. Dit betreft de relatie van het risicomanagement met het liquiditeitsvraagstuk van een onderneming. Mello en Parsons (1999) hebben hiervan een interessante uitwerking gepubliceerd. Daarin stellen zij als doel van het risicomanagement dat te allen tijde de middelen voor het doen van de geplande investeringen moeten worden gevonden omdat anders het strategisch plan in gevaar kan komen hetgeen noodmaatregelen zou kunnen veroor- 
zaken. Die investeringen zelf zijn ook deel van de toekomstige kasstroom naast de operationele resultaten. Het gaat erom het negatieve liquiditeitseffect van toekomstige tegenvallende bedrijfsresultaten zo perfect mogelijk te combineren met het meevallend liquiditeitseffect van hedge-instrumenten. Die laatste moeten op dat doel worden gericht: zorg dat te allen tijde voldoende liquiditeiten aanwezig zijn voor de uitvoering van het strategisch plan. Hedging en financiering zijn onderling altijd verweven.

\section{Het minimaliseren van het financieeltechnische liquiditeitsrisico}

Het hiervoor beschreven 'algemene' liquiditeitseffect heeft betrekking op het wel of niet doorgaan van investeringen en de rol van derivaten om dit te reguleren. Het liquiditeitsrisico (kans op kastekorten) moet hierbinnen afnemen juist door het gebruik van derivaten. Los daarvan staat echter het 'financieeltechnische' liquiditeitseffect van een gekozen financieel instrument zelf. Hiermee wordt bedoeld dat tijdens de looptijd van een financieel instrument onderpanden of margin calls kunnen plaatsvinden (zie figuur 1) die uiteraard ook als een liquiditeitseffect kunnen worden betiteld. Hierdoor neemt het liquiditeitsrisico van een onderneming die derivaten gebruikt, juist toe. Woningcorporatie Vestia heeft moeten ondervinden dat dit financieeltechnische liquiditeitseffect van het gebruik van derivaten zelfs zodanige vormen kan aannemen dat het 'algemene' liquiditeitseffect niet wordt behaald en investeringen alsnog moeten worden uitgesteld of geannuleerd. Het middel is daarbij erger dan de kwaal. Zoals reeds opgemerkt kan dit leiden tot een vlucht uit derivaten richting interne hedge of richting afwenteling van risico's via de vermogensmarkten (zie figuur 2).

\subsection{De keuze uit separate versus ingebouwde derivaten}

Ten minste drie overwegingen springen in het oog bij de keuze tussen separate en ingebouwde derivaten.

\section{Transparantieverschil}

Separate derivaten zijn voor de buitenwacht normaal gesproken onzichtbaar omdat deze transacties en de wijzigingen hierin in de loop van een jaar gewoonlijk niet door een onderneming worden gepubliceerd. Het zijn transacties die in beginsel dagelijks via de treasury-afdeling tot stand komen en naar believen kunnen worden ingetrokken. De ingebouwde derivaten zijn wel zichtbaar voor derden en kunnen niet zomaar worden ingetrokken. Rating agencies en beleggers zullen met de aanwezigheid van separate derivaten daarom moeilijk rekening kunnen houden. De transparantie ontbreekt. Daardoor kan het zicht op de kwaliteit van de vermogensstructuur in de balans vertroebeld worden (zie onder d in paragraaf 5.4). Het beeld is onvolkomen en incompleet. Dit heeft een belangrijk gevolg. Wat een onevenwichtige vermogensstructuur lijkt te zijn uitgaande van een gegeven balans, hoeft dat lang niet altijd te zijn als derivaten voorzien in de vermeende tekortkomingen. Maar ook omgekeerd: wat gezond oogt, kan onevenwichtig zijn wanneer separate derivaten het beeld van de toekomstige geldstromen in de financieringssfeer in sterke mate verkeerd beïnvloeden.

\section{Ingebouwde derivaten alleen bij emissies mogelijk}

Als de onderneming niet van plan is extern vermogen aan te trekken, kan zij geen gebruikmaken van ingebouwde derivaten. Als ze dan toch met derivaten actie wil ondernemen kunnen dat alleen separate derivaten zijn die altijd kunnen worden aangegaan.

\section{Emissiesuccesversterkend: synergie-effect}

Ingebouwde derivaten kunnen een belangrijke rol spelen bij het succesvol aantrekken van extern vermogen, hetzij eigen hetzij vreemd vermogen. We noemden reeds het voorbeeld van de converteerbare obligatie. De attractie om ooit de lening te mogen converteren in aandelenvermogen is waardevol voor beleggers die daarop mogelijk meer belangstelling hebben om op de lening in te tekenen (Duffhues, 2006b) zodat de onderneming effectief over het extra vermogen kan beschikken. Derivaten fungeren hierbij in dienst van het emissiesucces en derhalve in dienst van de financiering van de onderneming.

\subsection{Schematisering van mogelijke hedgestrategieën}

Doorgaans wordt de term 'hedging' geïnterpreteerd als het afdekken van een bepaald risico door middel van een externe financiële transactie. Toch kan ook wanneer het risico op eigen kracht (van binnenuit) worden bestreden van hedging worden gesproken. Er zijn bijvoorbeeld soms mogelijkheden om afnemers een hogere prijs te vragen als zich een risico manifesteert. In het schema in figuur 2 onderscheiden we daarom interne en externe hedges die als samenstel moeten worden geoptimaliseerd. Deze worden in figuur 2 geillustreerd en ingedeeld aan de hand van een valutaprobleem. De ondernemingsleiding moet een keuze maken uit deze twee hedgemethoden of uit een combinatie. Eerder werd reeds gewag gemaakt van de mogelijkheid om een valutacocktail te creëren. Deze ressorteert onder de interne hedges waardoor externe hedges ten minste voor een deel overbodig worden (Soenen, 1991). Ook kunnen bepaalde participanten in de onderneming fungeren als risicodrager voor een risico van de onderneming, bijvoorbeeld doordat werknemers geen loonsverhoging ontvangen of zelfs een loonsverlaging of ontslag moeten accepteren als het risico zich daadwerkelijk manifesteert. Figuur 2 is weliswaar toegespitst op valutarisicobeheersing maar heeft algemene geldigheid. Voor toelichting wordt verwezen naar Duffhues (2006a). 


\section{Empirisch onderzoek}

Ondanks de mogelijke negatieve effecten is het gebruik van derivaten in ondernemingen zeer wijdverbreid en dat geldt al geruime tijd. Uit allerlei wetenschappelijk onderzoek blijkt dat ondernemingen in de praktijk bijna zonder uitzondering gebruikmaken van derivaten voor hun risicomanagement. Daarbij gaat het steevast om de beheersing van met name de volgende drie bronnen van risico: het renterisico, het valutarisico en het grondstoffenprijsrisico. Ondernemingen maken gebruik van de in figuur 1 genoemde mogelijkheden om met behulp van derivaten deze risico's te beheersen. Zeer populair zijn de onderhandse termijncontracten, zoals het valutatermijncontract en het future rate agreement (FRA) (beide worden afgesloten met vooral banken), en daarnaast de swaps (in het bijzonder renteswaps en in wat mindere mate valutaswaps). Dat hierbij onbedoeld ook grote tekorten c.q. verliezen kunnen ontstaan die zelfs tot continuitteitsproblemen kunnen leiden, is vele malen gebleken, ook in 2012 in de zogeheten Vestia-casus waarin het gaat over een Nederlandse woningcorporatie die massaal renteswaps met banken afsloot maar dat niet deed op doordachte gronden (Hoogendoorn, 2013). De eerder genoemde woorden van Warren Buffett uit 2003 waren zeker van toepassing op deze casus.

Ook academische auteurs zijn nagenoeg zonder uitzondering overtuigd van het waardecreërende potentieel van derivaten. De vraag is echter of dat potentieel ook blijkt uit empirisch onderzoek. In de literatuur is een aantal studies verschenen waarvan de belangrijkste zijn samengevat in het onderzoek van Smithson en Simkins (2005). Hun onderzoek bevestigde in het algemeen de conclusies van de praktijkmanagers en van de academici dat risicomanagement van ondernemingen waarde creëert. Grote multinationale ondernemingen bleken te profiteren van hun diversiteit en de daarmee samenhangende natuurlijke hedges. Daarmee wordt bedoeld dat als gevolg van de spreiding van activiteiten en vestigingen derivatengebruik vaak niet nodig was. De voor ons doel cruciale vraag of er een positieve relatie werd aangetroffen tussen het gebruik van derivaten en de marktwaarde van de onderneming werd in dit Amerikaanse survey-onderzoek onderzocht voor een viertal subgroepen van ondernemingen en risico's die door andere onderzoekers waren ingesteld. De onderzoeksvragen waren als volgt.

a. Zijn financiële instellingen gevoelig gebleken voor het rente- en valutarisicobeheer van deze instellingen?

b. Zijn industriële ondernemingen gevoelig gebleken voor het valutarisicobeheer van deze ondernemingen?

c. Zijn grondstoffenverbruikende ondernemingen gevoelig gebleken voor het beheer van het prijsrisico van grondstoffen? d. Zijn grondstoffenproducerende ondernemingen gevoelig gebleken voor het beheer van het prijsrisico van grondstoffen?

In totaal ging het om tien studies verdeeld over deze groepen. Als maatstaf voor de marktwaarde werd telkens gekozen voor Tobin's Q. Dat is de verhouding van de marktwaarde van de onderneming en de vervangingswaarde van de activa.

Het onderzoeksresultaat voor de ondernemingen sub $\mathrm{a}$ en $\mathrm{b}$ toonde een positieve samenhang. Hierbij varieerde het waardevoordeel van $1,1 \%$ tot zelfs $4,8 \%$. Hedgende ondernemingen sub $c$ toonden een positieve samenhang tussen afdekking en marktwaarde. Vliegmaatschappijen die het kerosineverbruik afdekten, behoorden tot deze groep c. Grondstoffenprodu-

\section{Figuur 2 Interne en externe hedges inzake valutabeheersing (Duffhues, 2006a)}

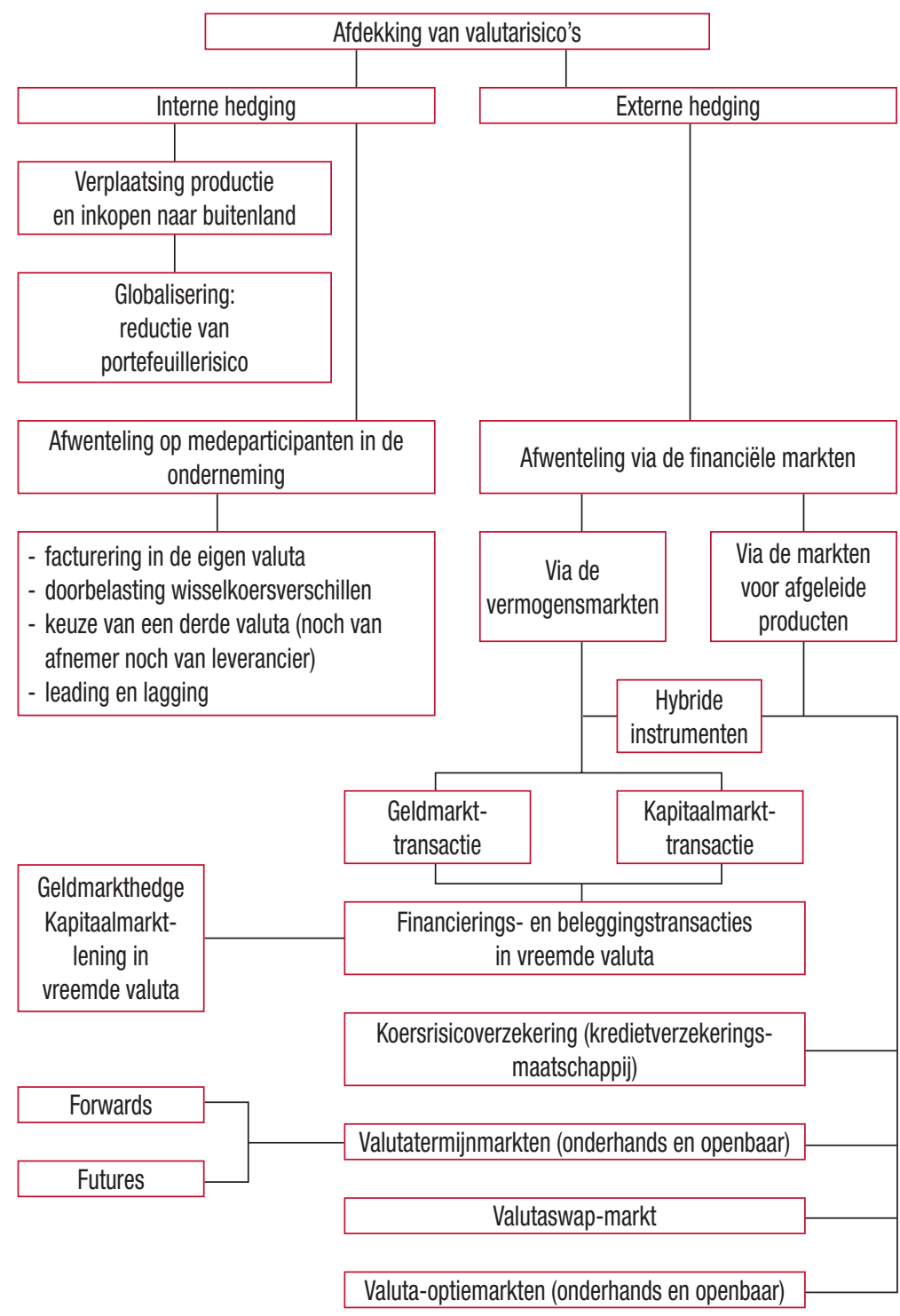


centen (zie d) toonden geen duidelijke samenhang tussen waarde en risicomanagement. Er was ofwel geen of zelfs een negatieve samenhang. Het ging hierbij vooral om olie- en gasproducenten. De beleggers in deze ondernemingen wilden het prijsrisico blijkbaar juist wel lopen; afdekking door de onderneming werd eerder afgestraft dan verwelkomd. Dat is begrijpelijk omdat voor individuele beleggers niet afdekken een hedge kan betekenen.

Het totale beeld is ondanks dit overzichtsartikel van tien deelstudies toch nog onduidelijk omdat de interpretatie van de onderzoeksresultaten niet eenduidig is. Toch lijkt het erop dat vooral financiële instellingen gevoelig zijn (hogere Tobin's Q) voor rente- en valutaveranderingen. Industriële ondernemingen met veel omzet in vreemde valuta's lijken eveneens meer gevoelig voor afdekking van valutarisico dan meer op de binnenlandse markt gerichte ondernemingen. Dit betekent dat de gerapporteerde onderzoeksresultaten op hoofdlijnen in overeenstemming zijn met de pro-argumenten genoemd in paragraaf 3 . De nadelen genoemd in paragraaf 3 hebben blijkbaar niet altijd kunnen voorkomen dat derivaten werden gebruikt voor het hedgen van posities.

Een interessant Nederlands enquêteonderzoek was van De Jong, Macrae \& Nijman (2000). Uit die studie bleek dat ook Nederlandse ondernemingen op grote schaal gebruikmaakten van derivaten. De grootste ondernemingen waren de grootste gebruikers (88\%). Het onderzoek was toegespitst op de problematiek van valutarisico. Slechts 60\% van de Nederlandse ondernemingen vond het managen van de volatiliteit van hun kasstromen belangrijk. Ook waagden veel ondernemingen zich aan het voorspellen van valutakoersen hetgeen in strijd is met het 'advies' van de theorie. De onderzoekers concludeerden dat er een hiaat bestond tussen de hedgepraktijken van Nederlandse ondernemingen en hetgeen de literatuur aangeeft. Onder andere werd bevestigd dat aan de economische exposure door ondernemingen te weinig expliciete aandacht werd besteed. Ook bleek uit waargenomen speculatief gedrag dat men de neiging vertoont de markt te kunnen verslaan.

\section{Samenvatting en conclusies}

In een perfecte vermogensmarkt ${ }^{13}$ zijn financiële derivaten overbodige financiële instrumenten omdat ze daar kunnen worden nagebootst als combinaties van andere reeds bestaande financiële instrumenten. Perfecte vermogensmarkten bestaan echter niet. In de imperfecte wereld zijn financiële derivaten naar hun aard nuttige financiële instrumenten met een afgeleid karakter: hun waarde ontlenen ze in belangrijke mate aan de prijs van de onderliggende waarde zoals een rentestand, een valutakoers of een goudprijs die alle onze- ker zijn. Er is een ongekend uitgebreide verzameling van derivaten in de onderhandse en openbare markten beschikbaar gemaakt. Meestal zijn het tamelijk complexe instrumenten waardoor gemakkelijk misverstanden kunnen ontstaan bij eindgebruikers en bij het grote publiek dat eenzijdig wordt geïnformeerd over mislukt gebruik van deze instrumenten. Derivaten kunnen belangrijke nadelen hebben waartoe zeker moet worden gerekend dat tijdens de looptijd van het derivaat uitgaande kasstromen naar de tegenpartij kunnen ontstaan bij bepaalde prijsontwikkelingen van de onderliggende waarde. Deze doen afbreuk aan het primaire doel: de liquiditeit van de onderneming optimaal beheersen. Desondanks is de overwegende economische betekenis van derivaten dat zij op een efficiente manier het financiële risicoprofiel van een onderneming (voortdurend) kunnen wijzigen en daardoor flexibiliteit aanbrengen in een dynamische financiële omgeving. Dit streven komt neer op het op een bepaald tijdstip zoeken naar de optimale hedgestrategie waarbij het geschikte derivaat wordt gekozen niet als 'stand alone'-beslissing maar uitsluitend in samenhang met de keuze van de toekomstige investeringen en daarmee met de toekomstige concurrentiepositie en rekening houdend met de mogelijkheid van tussentijdse uitgaande kasstromen. Dit laatste kan worden gereguleerd door jegens de tegenpartij in plaats van uitgaande kasstromen zoveel mogelijk onderpand aan te bieden. Op een later tijdstip kan een beslissing worden herroepen als de markten zich hebben gewijzigd. Deze analyse is gericht op het bewaren van de liquiditeit van de onderneming zodanig dat de marktwaarde van de onderneming wordt gediend.

Derivatengebruik moet worden ingebed in het algemene integrale, holistische risicomanagement van de onderneming. Partiële hedgingactiviteiten zijn niet zaligmakend, soms zelfs gevaarlijk want mogelijk contraproductief. Toch domineert het partiële risicomanagement in de jaarverslaggeving van ondernemingen: specifieke risico's worden geïsoleerd besproken (Duffhues, 1993). Er wordt ten onrechte een daarop afgestemd risicomanagement geformuleerd. Economische exposures blijven daarbij nagenoeg buiten beschouwing. In de bepleite integrale benadering wordt altijd gestart met een analyse van het risicoprofiel van de totale onderneming, een strategische benadering (Emanuels \& De Munnik, 2005). De hieruit voortvloeiende scenario's van de toekomstige liquiditeit leveren de basis voor de te contracteren hedge-instrumenten (Mello \& Parsons, 1999). Mogelijk hierbij optredende onaanvaardbare uitkomsten van de toekomstige liquiditeit van de onderneming die men bij voorkeur niet op de emissiemarkt voor aandelen of obligaties wil bestrijden, verdienen inzet van in dat specifieke scenario passende derivaten zoals diverse vormen van termijn- 
contracten, opties of combinaties daarvan. Zo geformuleerd gaat het uitsluitend om separate derivaten en de keuze daaruit. Is externe financiering wel passend dan gaat het ook over de keuze van ingebouwde derivaten: emitteren we een standaard gewone obligatielening of een gestructureerde lening met diverse ingebouwde opties? Figuren 1 en 2 bieden ondersteuning en belangrijk geachte criteria ter ondersteuning van dergelijke keuzes in de praktijk. De bestrijding van onaanvaardbare liquiditeitsuitkomsten op de hier beschreven wijze waarbij als hoogste doelstelling de continuiteit van de onderneming wordt gediend, onderstreept de noodzaak om beslissingen over financiering en derivatengebruik altijd simultaan te nemen. Zo kunnen bijvoorbeeld vaste rentelasten worden gecreëerd zowel door het afsluiten van vastrentende leningen als door variabelrentende leningen aangevuld met een geschikte renteswap. Derivaten spelen in dit laatste geval een bijzondere rol (hetzij als ingebouwde hetzij als separate derivaten). Derivaten zijn niet onmisbaar maar heel vaak wel nuttig (Boot \& Ligterink, 1995). De praktijk toont dit ook duidelijk aan gezien het empirisch onderzoek. Dat neemt niet weg dat er veel moet worden geleerd van wat desondanks misgaat vaak wegens conceptuele (welke is de exposure?) en operationele tekorten (Fraser \& Simkins, 2007; Stulz, 2008; Lynch, 2011). De wereldwijde financiële crisis die in 2007 intrad, is daarvan een niet te ontkennen voor- beeld: derivaten kunnen ook worden gecontracteerd door speculanten die niets te verzekeren hebben, derhalve geen initiële exposure hebben. Maatschappelijk kan dit tot grote problemen leiden zoals de inmiddels ingetreden bankencrisis die neerkomt op het abusievelijk volgen van het partiële of micro-hedginggedrag door een aantal voor het financiële systeem belangrijke banken terwijl gedrag volgens de integrale of macromethode had moeten domineren.

Dit artikel als geheel overziende kan worden gesteld dat de aandacht voor het liquiditeitsvraagstuk van ondernemingen dat in de literatuur verloren leek dankzij de aandacht voor optimaal risicomanagement (al dan niet met inzet van derivatengebruik) in feite weer terug is op de plek waar deze aandacht moet liggen. Optimale hedgestrategieën zijn in de kern niets anders dan een zeer belangrijke component van het streven naar optimale liquiditeit met als doel te allen tijde te overleven en het strategisch waardecreërende plan van de organisatie te kunnen uitvoeren. Derivaten zijn daarbij een onmisbaar en efficiënt pakket van financiele instrumenten.

Prof. dr. Piet J.W. Duffhues is emeritus hoogleraar Ondernemingsfinanciering aan Tilburg University.

\section{Noten}

Een achtergestelde lening wordt door ratinginstituten gezien als deels eigen vermogen en deels vreemd vermogen bijvoorbeeld in een 50/50-verhouding (Ryan et al., 2007). Het is een vorm van een hybride lening. De structurering van dergelijke achtergestelde leningen is erop gericht zowel het garantievermogen te vergroten met een extra component naast het eigen vermogen als de aftrekbaarheid van de rentelasten veilig te stellen. (Vergelijk ook Duffhues, 2006b).

D. De aangevoerde reden is veelal dat men geen verwatering van de winst per aandeel en/of de zeggenschap wenst. Merkwaardig in deze redenering is dat verwatering van de winst per aandeel lang niet altijd hoeft op te treden omdat het nieuwe vermogen soms een aanzienlijke winstvergroting betekent, ook op korte termijn. Bovendien mist men het voordeel van een betere solvabiliteit. Deze kortzichtige financieringsstrategie van de banken heeft veel schade toegebracht aan de weerbaarheid van deze instellingen toen de financiële crisis zich in 2007 openbaarde.

3. Warren Buffett schreef dit in een brief van 8 maart 2003 aan de aandeelhouders van zijn be- leggingsmaatschappij Berkshire Hathaway. 4. Een goed voorbeeld is de onderneming PostNL die in 2012/2013 zwaar moest reorganiseren om de continuitteit te handhaven. Zo werd de dividendbetaling wegens gebrek aan liquiditeit opgeschort. Vergelijkbaar was in dezelfde periode Koninklijke KPN dat het dividend aanzienlijk reduceerde en zelfs een aandelenemissie plande om het tekort aan liquide middelen op te vangen. Een ander voorbeeld is Koninklijke Philips dat in de jaren negentig van de vorige eeuw Operatie-Centurion bedacht om ernstige continuïteitsproblemen het hoofd te bieden. De beursonderneming Royal Imtech bleek in het voorjaar van 2013 als betrekkelijk jong beursfonds plotseling in grote financiële moeilijkheden te verkeren. Ten slotte kunnen in het algemeen de banken worden genoemd omdat zij gewoonlijk met zeer veel vreemd vermogen financierden en aandelenemissies uit de weg gingen. Daardoor waren zij aangewezen op grootschalig gebruik van derivaten.

5 Een voorbeeld in Nederland is het C\&A-concern dat een besloten karakter bezit. Het is een familievennootschap. Familievennootschappen worden in onderzoek vaak gezien als in sterke mate in staat tot zelffinanciering. 6 Voor een afwijkende mening zie Schreuder (2013).

7. Let wel: strikt genomen zijn ook fiscale en verslaggevingsaspecten niet relevant in een perfecte vermogensmarkt. Er is geen verstorende invloed van belastingen noch van enige 'window dressing'- invloed in de jaarrekening. Zoals gezegd bestaat die ideale wereld niet, zelfs niet voor de bedoelde 'betere' ondernemingen.

8_ Zie eindnoot 2.

9 In het kader van waardemaximalisatie is het in de verslaggevingsliteratuur vaak gemaakte onderscheid tussen afdekking van kasstroomrisico en van reële-waarderisico niet relevant. Ook kasstroomrisico wordt verwerkt in een (contante) waarde. Verwezen wordt naar de Vries \& Veuger (2013).

10 Een transactie-exposure is een geldbedrag waarvan de waarde in de toekomst niet vaststaat. Denk aan een debiteurenvordering in vreemde valuta; de waarde hiervan in euro's kan onder invloed van wisselkoersveranderingen stijgen of 
dalen voordat betaling wordt ontvangen van de afnemer. Dit valutarisico kan worden afgedekt met behulp van derivaten. Een translatie-exposure is een geldbedrag waarvan de waarde eveneens ter discussie staat op een toekomstig tijdstip maar zonder dat sprake is van een kasstroom op dat moment. Het gaat hierbij om een toekomstige balansdatum zonder het voornemen om het geldbedrag dan te ontvangen of te betalen. Een voorbeeld van dit meer boekhoudkundige concept van een risico-object is de waarde in euro's van een buitenlandse deelneming. Een economische exposure is het geldbedrag dat de marktwaarde van de onderneming weerspiegelt; door ontwikkelingen in bijvoorbeeld de rentetarieven of wisselkoersen kan deze waarde stijgen of dalen. Hedging van deze exposure beoogt een daling te voorkomen. Voor uitgebreide toelichting op deze exposureconcepten zie Duffhues (2006a).

11 In feite hebben alle financieringsvormen een hybride karakter. Daarvan uitgaande is hybride vermogen een pleonasme. In dit artikel wordt de term hybride vermogen in aansluiting bij het spraakgebruik ietwat beperkt gehanteerd (zie eindnoot 12)

12. De belegger in een achtergestelde lening moet enerzijds accepteren dat de marktwaarde van zijn belegging kan dalen beneden de nominale waarde hetgeen een positie van een geschreven of verkochte putoptie op de marktwaarde van de debiteur impliceert. Anderzijds kan deze belegger niet meer verliezen dan die nominale waarde waarna als de verliezen van de onderneming cumuleren de belegger in gewoon vreemd vermogen verlies gaat lijden (afstempeling gewone schulden). Dit komt voor de houder van de achtergestelde lening overeen met de positie van een gekochte putoptie op de marktwaarde van de debiteur. Derhalve houdt hij twee putposities in combinatie met de lening (Duffhues, 2006b).

Als implicatie wordt opgemerkt dat de houder van een gewone niet-achtergestelde schuld ook een positie inneemt als houder van een geschreven putoptie op de marktwaarde van de debiteur maar geen long put houdt omdat de markwaarde van een onderneming nooit negatief kan zijn. Het verschil tussen gewone en achtergestelde lenin- gen is bijgevolg slechts gradueel. Zelfs het verschil tussen achtergestelde leningen en gewone aandelen is in deze context slechts gradueel: ook aandelenbeleggers houden een long put omdat zij niet hoeven bij te storten als de ondernemingswaarde daalt tot beneden het niveau van het totale vreemd vermogen.

Het is wellicht voor velen verrassend te moeten concluderen dat in essentie alle vormen van financiering een short putoptie op de marktwaarde van een onderneming in zich dragen. Dat geldt dus ook voor een gewone vastrentende lening. Strikt genomen zijn alle financieringsvormen dus hybride vermogensvormen. In paragraaf 5.3 en in figuur 2 hebben wij de lading van de term hybride vermogen echter beperkt tot die vormen waarbii er naast de genoemde (niet-onderscheidende) short putoptie nog een of meer andere derivaten zijn ingebouwd in het financieringscontract.

13 De lading van perfecte financiële markten omvat onder andere het concept van de aanwezigheid van 'complete' financiële markten (Tempelaar \& Smid, 1995) maar ook de afwezigheid van transactiekosten en belastingen.

\section{Literatuur}

- Aïd, R., Chemla, G., Porchet, A., \& Touzi, N. (2011). Hedging and vertical integration in electricity markets (CEPR Discussion Paper No. DP8313). Geraadpleegd op http://ssrn. com/abstract $=1812078$.

- Boot, A.W.A., \& Ligterink, J.E. (1995). Naar een verantwoord gebruik van derivaten. Economisch Statistische Berichten, 80(4004), 334-337.

- Bulkmans, R. (2013). Kenmerken en waarde van derivaten. Maandblad voor Accountancy en Bedriffseconomie, 87(6), dit nummer.

- Doherty, N.A. (2005). Risk management, risk capital, and the cost of capital. Journal of Applied Corporate Finance, 17(3), 8-17.

- Duffhues, P.J.W. (1993). De onweerstaanbare opkomst van de financiële markten voor afgeleide produkten. VBA Journaal, 9(3), 2-7.

- Duffhues, P.J.W. (2000). Ondernemingsfinanciering: Oriëntatie op integratie (Proefschritt, Tilburg University, Tilburg). Deventer: Kluwer.

- Duffhues, P.J.W. (2002a). Ondernemingsfinanciering en vermogensmarkten: Waardeschepping door financiële analyse, werkkapitaalbeheer en investeringsbeslisisngen (3th ed.). Groningen: Stenfert Kroese.

- Duffhues, P.J.W. (2002b). Recente ontwikkelingen in financieel risicomanagement.
Maandblad voor Accountancy en Bedriffseconomie, 76(4), 138-149.

- Duffhues, P.J.W. (2006a). Ondernemingsfinanciering en vermogensmarkten: Waardeschepping door financierings-, dividend- en riskmanagementbeslissingen (3th ed.). Groningen: Stenfert Kroese.

- Duffhues, P.J.W. (2006b). Hybride vermogensvormen. In P.J.W. Duffhues (Ed.), Financiering, belegging en verzekering (pp.57-72). Deventer: Kluwer.

- Duffhues, P.J.W. (2009). The financial crisis: A reproachable risk management error of banks? FIRST Quarterly, 6, 8-10.

- Emanuels, J.A., \& Munnik, W.G. de (2005). Enterprise Risk Management als risicobeheersingssysteem. Management Control \& Accounting, 9(6), 30-34.

- Fraser, J.R.S., \& Simkins, B.J. (2007). Ten common misconceptions about enterprise risk management. Journal of Applied Corporate Finance, 19(4), 75-81.

- Froot, K.A., Scharfstein, D.S., \& Stein, J.C. (1994). A framework for risk management. Journal of Applied Corporate Finance, 7(3), 22-32.

- Hoogendoorn, M.N. (2013). Derivaten en risicomanagement. Maandblad voor Accountancy en Bedrijfseconomie, 87(6), dit nummer.

- Jong, A. de, Macrae, V., \& Nijman, T. (2000). Hedgen van valutarisico in Nederland: discrepantie tussen theorie en praktijk? Maandblad voor Accountancy en Bedrifseconomie, 73(6), 251-263.

- Lynch, T. (2011). Derivatives: A twenty-first century understanding (Indiana Legal Studies Research Paper No.187). Geraadpleegd op http://ssrn.com/abstract=1785634.

- Mello, A.S., \& Parsons, J.E. (1999). Strategic hedging. Journal of Applied Corporate Finance, 12(3), 43-54.

- Mello, A.S., \& Parsons, J.E. (2000). Hedging and liquidity. Review of Financial Studies, 13(1), 127-153.

- Modigliani, F., \& Miller, M. (1958). The cost of capital, corporation finance and the theory of the firm. American Economic Review, 48, 261-297.

- Ryan, K., Ross, J., \& Yen, J. (2007). The new wave of hybrids: Rethinking the optimal capital structure. Journal of Applied Corporate Finance, 19(3), 56-64.

- Smithson, C., \& Simkins, B.J. (2005). Does risk management add value? A survey of the evidence. Journal of Applied Corporate Finance, 17(3), 8-17. 
- Soenen, L.A. (1991). When foreign exchange hedging doesn't help. Journal of Cash Management, 11(6), 58-62.

- Schreuder, H. (2013, 25 februari). Geld is voor grootbedrijf geen issue. Het Financieele Dagblad.

- Srinivasulu, S.L (1981). Strategic response to foreign exchange risks. Columbia Journal of World Business, 16(1), 13-23.

- Stulz, R.M. (1996). Rethinking risk management. Journal of Applied Corporate Finance,
9(3), 8-24.

- Stulz, R.M. (2003). Risk management \& derivatives. Mason, OH: Thomson-South-Western.

- Stulz, R.M. (2004). Should we fear derivatives? Journal of Economic Perspectives, 18(3), 173-192.

- Stulz, R.M. (2008). Risk management failures: What are they and when do they happen? Journal of Applied Corporate Finance, 20(4), 39-48.

- Tempelaar, F.M. \& Smid, P.P.M. (1995). Ideali- serende denkbeelden omtrent de vermogensmarkt, In: A.B. Dorsman, C.H. Veld en A.H.F. Verboven (red.). De Nederlandse Vermogensmarkt (pp.16-39), Delwel.

- Vries, K.J. de, \& Veuger, P. (2013). Derivaten in de jaarrekening. Maandblad voor Accountancy en Bedrijfseconomie, 87(6), dit nummer.

- Woods, M. (2007). Linking risk management to strategic controls: A case study of Tesco PIc. International Journal of Risk Assessment and Management, 7(8), 1074-1088. 